\title{
28 Research Square \\ Cell disruption caused by mutant prelamin A protein points to origin of progeria
}

\section{Veronika Eisch \\ Xiang Lu \\ Diana Gabriel \\ Karima Djabal}

\section{Video Abstract}

Keywords: Technical University Munich (TUM), Oncotarget, progerin, lamin, mitosis, CENP-F, HutchinsonGilford progeria, premature aging, aging, nucleus, nuclear envelope, chromosome, kinetochore, lamina, lamins, chromatin lagging, senescence, binucleated cell, genomic instability, endoplasmic reticulum

Posted Date: September 20th, 2019

DOl: https://doi.org/10.21203/rs.2.15047/v1

License: (c) (i) This work is licensed under a Creative Commons Attribution 4.0 International License. Read Full License 


\section{Abstract}

Critical defects that compromise the nucleus during cell division could be the basis for the ageaccelerating effects of people living with progeria. Hutchinson-Gilford progeria syndrome is a genetic disorder that causes premature aging. Affecting one in 8 million newborns worldwide, the disorder is extremely rare-and fatal. The rapid aging of the cardiovascular system causes death due to heart attack or stroke in patients by their mid-teens. Progeria is caused by a tiny point mutation in the lamin A gene. This gene is responsible for producing structural proteins called lamins, which form the scaffolding that holds the cell nucleus together. The mutated form of prelamin A called progerin destabilizes the cell nucleus -the genetic control center of cells. The result is the fast-aging effects observed in progeria. But the link from gene mutation to physical disorder has remained a mystery. Previous studies have looked only at models of progeria, not at actual patient cells. Or they've tracked progerin only through the stages leading up to cell division. Now researchers have followed progerin as it wreaks its disruptive effects on the cells of patients with progeria throughout the entire cell division process. Compared with normal cells, cells containing progerin trapped structural components of the nuclear membrane from reaching their required post during cell division. Normally, those proteins lie throughout the cell during division before being called back to the nuclear membrane at the end of mitosis. Trapping in progeria cells delayed the reformation of the nuclear envelope, greatly deforming the boundaries of cell nuclei. Perhaps the most disruptive defect caused by progerin was the displacement of the protein CENP-F. This protein enables cellular machinery to pull chromosomes apart during cell division. But in the presence of progerin, the protein is dislodged, causing vital chromosome material to lag behind. This interference could tie progerin directly to the genetic instability observed in patients with progeria-as the intrusive effects and amount of progerin in the cell accumulate with each round of division. Because of sequence similarities between progerin and CENP-F at their terminal end, protecting CENP-F could be one way of preserving genome integrity in patients with progeria. More work is needed before the implications for possible treatment can be sorted out. But the researchers hope these findings invite further studies to unravel the direct effects of progerin and to develop therapeutic strategies for fighting progeria. 